\title{
IMPLEMENTING SUGGESTOPEDIA LEARNING METHOD IN DEVELOPING WRITING ABILITY OF CIVIL ENGINEERING STUDENTS
}

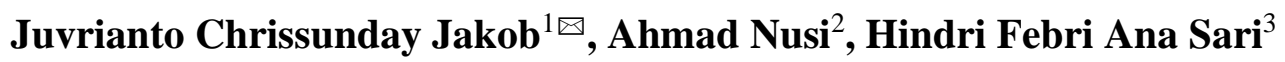 \\ ${ }^{1,2}$ Jurusan Teknik Sipil, Politeknik Negeri Ambon, Ambon, Indonesia \\ ${ }^{3}$ Jurusan Administrasi Niaga, Politeknik Negeri Ambon, Ambon, Indonesia, Jl. Ir. M. Putuhena, Rumah \\ Tiga, Tlk. Ambon, Kota Ambon, Maluku. 97234. \\ ${ }^{\otimes}$ Email: ${ }^{1}$ juvrianto.jakob@polnam.ac.id
}

\begin{abstract}
This present research conducted in Civil Engineering Department and reports the implementation of Suggestopedia Learning Method in developing students' writing ability. The objective of the research is to find out whether or not the first semester students of TKJJ Study Program in Civil Engineering Department of Politeknik Negeri Ambon can develop their writing ability through Suggestopedia Learning Method. A quasi-experimental design as a part of quantitative research employed in this study. The data is obtained through the Pretest and Posttest. The data sample was taken using cluster random sampling. Based on the result of the research, it is concluded that: The result of the data analysis showed that the teaching through suggestopedia significantly improved the writing ability of the first semester students of TKJJ Study Program in Civil Engineering Department of Politeknik Negeri Ambon. It was proved by the mean score on pretest that was 47.077 and the posttest that was 79.35. In addition, after analyzing the data by using the test formula, the result of t-test value was 3.746 and t-table value 1,684. It means that the t-test value was greater than $t$-table value it indicated that $H_{1}$ was accepted and $H_{0}$ was rejected. Therefore, the hypothesis of the research is the students' writing ability that was taught through Suggestopedia Learning Method was better than the students who were taught through conversation method.
\end{abstract}

Keywords: Civil Engineering Students, Suggestopedia, Writing Ability,

\begin{abstract}
Abstrak
Penelitian ini dilaksanakan di Jurusan Teknik Sipil dan melaporkan tentang pengimplementasian Suggestopedia Learning Method dalam mengembangkan kemampuan menulis mahasiswa. Penelitian ini bertujuan untuk menemukan apakah kemampuan menulis mahasiswa semester satu Program Studi TKJJ di Jurusan Teknik Sipil Politeknik Negeri Ambon dapat berkembang dengan menggunakan Suggestopedia Learning Method. Metode yang digunakan adalah penelitian semu sebagai bagian dari penelitian kuantitatif digunakan dalam penelitian ini. Data diperoleh dari pretest and posttest. Sampel dipilih dengan menggunakan cluster random sampling. Berdasarkan hasil penelitian, dapat disimpulkan bahwa: Hasil dari penelitian menunjukkan pengajaran melalui metode suggestopedia secara sinifikan dapat meningkatkan kemampuan menulis mahasiswa semester satu Program Studi TKJJ di Jurusan Teknik Sipil Politeknik Negeri Ambon. hal ini dibuktikan dari nilai rata-rata siswa pada saat pretest yaitu 47.077 dan meningkat pada saat posttest yaitu 79.35. setelah menganalisis data, ditemukan nilai t-test yaitu 3.746 dan t-table 1.684 (t-test lebih tinggi daripada t-table). Hal ini mengindikasikan bahwa HI diterima dan HO ditolak. Maka hipotesis yang diterima dalam penelitian ini yaitu kemampuan menulis mahasiswa yang diajar melalui suggestopedia lebih baik daripada mahasiswa yang diajar melalui metode konvensional.
\end{abstract}

Kata Kunci: Mahasiswa Teknik Sipil, Suggestopedia, Kemampuan Menulis

\section{Introduction}

The purpose of teaching English is to master four skills; they are listening, speaking, reading, and writing. Teaching and learning activity in writing need some skills for the students to master. Writing is recurrently useful the same as preparation for some other activity (Harmer, 2007).

Based on the researchers' observations, many students felt that writing was difficult. That's because there are too many components to go through in writing. Meyers (2005) writing is an 
action, a process of discovering and organizing our ideas, putting them on paper, reshaping and revising them. Therefore, in writing the students can express their idea, feeling, and opinion about something. Then, they can improve their grammar and vocabulary. To improve their writing ability there were some method and approaches has been employing in teaching writing. In this research, the researcher applied Suggestopedia Learning Method as a solution to improve the students writing ability.

According to Dardjowijojo (1996), there are five sophisticated approaches in language teaching such as Community Language Learning, Total Physical Response, the Natural Approach, the Silent way and suggestopedia.

This current approach is the priority to the role and the need of the students. Because of that, the researcher considers to use one of them to prove the effectiveness of suggestopedia in language teaching. Suggestopedia is the humanistic approach that prioritizes the student's needs.

Suggestopedia is a modern methodology in teaching foreign language coming from Bulgaria. A Bulgarian doctor, Georgi Lozanov in 1960, develops it. "Suggestopedia is a teaching system which makes the use of all the possibilities tender suggestion can offer" (Lozanov, 1978). It relies on the relaxation with the comfortable atmosphere. The teacher can create and provide the pleasant activity with a very comfortable environment so the students can enjoy and feel relaxed during the lesson. It involves the psychological, educational, artistic, and musical (Lozanov, 1978).

Based on the observation of the first semester students of TKJJ Study Program in Civil Engineering Department of Politeknik Negeri Ambon, the researcher found that the skill of students in writing was still low. It can be seen from their learning achievement; the mean score of the students in writing skill was 60 score rate, this score was categorized as very pool level. This score is unexpected based on standard in Polytechnic curriculum achievement where $2.66\left(\mathrm{~B}^{-}\right)$or 75 and categories us low poor level which based on standard classification.

\section{Writing definition}

There are definitions of writing given by some experts, as follow:

Harmer, (2001:86) "writing is a process and that we write is often heavily influenced by the constraints of genres, then these elements have to be present in learning activities."

Hyland, (2002:7) Writing is various kinds;

It can use as a means to express the writers' idea based on her experience, thoughts, and feelings. Moreover, in many school, writing is principally conduct to demonstrate knowledge of deconstextualised facts with little awareness of a reader beyond the teacher-examiner.

Based on the explanation above, the researcher assumes that writing was a way procedure language that comes from the head and we can share our idea if we cannot convey it orally. Beside that the writers use invention strategies and extensive planning to resolve the theoretical problem that each writing task presents.

\section{Definition of Suggestopedia}

Suggestopedia is one of teaching methods introduced by Bulgarian pychiatrit Georgi Lozanov in the 1960's. The main objection of this method is to motivate students by suggestion. In this method, six principal theoretical components make it different from the other methods. In addition, to achieve those components, it puts suggestions into practice by making use of instructional techniques. There are also three kinds of teaching tools used in 
suggestopedia such as, psychological means, didactic means, and artistic means. Another definition of what was suggestopedia was giving Richards and Richards and Rodgers 2001, Suggestopedia, also called Desuggestopedia, this method includes elements such as the use of relaxing music, art and the additional importance that is given to the learning environment as well as the authoritative behavior of the teacher.

Based on the statement above, suggestopedia is the method that includes elements such as the use of relaxing music, art and the additional importance that was given to the learning environment as well as the authoritative behavior of the teacher and how the human brain works and how we learn most effectively.

\section{Advantages of Suggestopedia}

Pineda (2013) there are some advantages of suggestopedia

1) Comprehensive input

By using this suggestopedia method, students can derive their affective filters. Suggestopedia classes, on the other hand, are held in ordinary rooms with comfortable chairs, an exercise that might also help them relax. Teachers can do many other things to lower affective filters.Thinking highly of students' Feeling.

2) Authority Concept

Students remember best and are most influenced by information that comes from an authoritative source, the teacher.

3) The double-planedness theory

This refers to learning from two aspects. They are both the conscious and subconscious aspects. Students can derive teaching objectives from direct instruction and the environment in which teaching takes place.

4) Peripheral learning

Suggestopedia encourages students to apply language more independently, requires more personal responsibility for self-study and gain higher selfconfidence. Peripheral information can also help encourage students to be more experimental, and seek non-teacher sources for language input. For example, students can make several sentences using grammatical structures that are placed on the walls of the classroom, describe a certain place in an English speaking country by looking at posters on the wall, etc. When students are successful in doing such independent activities, they will be more confident.

There are numbers of advantages of implementing Suggestopedia Learning Method that teacher can get during learning process in the classroom. The use of learning methods can indeed help students understand the learning material and this is in line with the research conducted by Jakob (2020) which found that using Communicative Fluency Activities can develop the students ability in writing descriptive text.

\section{Research Methodology}

This research employed quasiexperimental method, which applied one group experimental class and one group control class. The design was present as follow:

$\begin{array}{cccc}\text { Sampl } & \text { Pretes } & \text { treatmen } & \text { Posttes } \\ \mathbf{e} & \mathbf{t} & \mathbf{t} & \mathbf{t} \\ & \mathbf{O}_{1} & & \mathbf{O}_{2} \\ \text { E } & \mathbf{O}_{1} & \mathbf{X}_{1} & \mathbf{O}_{2} \\ \text { C } & & \mathbf{X}_{2} & \end{array}$

Where:

\begin{tabular}{|c|c|c|}
\hline $\mathrm{E}$ & : experimental class & \\
\hline $\mathrm{C}$ & : control class & \\
\hline $\mathrm{O}_{1}$ & : Pretest & \\
\hline $\mathrm{X}_{1}$ & : Treatment Experimental & Class \\
\hline $\mathrm{X}_{2}$ & : Treatment Control Class & \\
\hline $\mathrm{O}_{2}$ & : Posttest & \\
\hline
\end{tabular}

(Gay, Mills, Airaisian, 2006)

The data collected through the test was analyzed qualitatively. This quantitative 
analysis employs statistical calculation to test the hypothesis. To analyze the data collection, the researcher uses descriptive and inferential statistics. Some formulates apply in this research to process the data as follows:

1. Collecting raw score

To analyze data collecting of the test and fine out students score, the researcher uses following formula. Some formulas applied in this research to process the data as follows:

Collecting raw score

$=\frac{\text { Student }^{\prime} \text { guined score }}{\text { Maximum Score }}$ x 100

2. Computing the frequency and the rate percentage of the students:

$$
\mathrm{P}=\frac{F}{n} \times 100
$$

Where:

P: Percentage

$f$ : Item of frequency

$\mathrm{N}$ : Total number of responden

(Hatch and Farhady in Rahman, 2001)

3. To calculate the mean score between the result of pretest and posttest both experimental and control group, the researcher use the following formula:

$$
\overline{\mathrm{X}}=\frac{\sum X}{N}
$$

Where:

$$
\begin{array}{ll}
\mathrm{X} & : \text { Mean score } \\
\sum_{\mathrm{N}} \mathrm{x} & : \text { Total of row score } \\
& \text { : the number of subject }
\end{array}
$$

(Gay, Mills, Airasian, 2006)

4. Finding out the standard deviation by using the following formula:

$$
\begin{aligned}
& \mathrm{SD}=\sqrt{\frac{S S}{n}} \text { in which } \\
& \mathrm{SS}=\sum X^{2}-\frac{\left(\sum X\right)^{2}}{n}
\end{aligned}
$$

Where:

SD : Standard Deviation

SS : The square root of the sum of squares

$\mathrm{n}$ : The number of students

$\sum X$ : The sum of square

(Gay, Mills, Airasian, 2006)
5. Finding the difference of means score between pretest and posttest by calculating the value of the test, applying for non-independent sample t- test formula:

$$
\begin{aligned}
& \mathrm{t}=\frac{\bar{X}_{1-\bar{X}_{2}}}{\left(\frac{S S_{1+S S_{2}}}{n_{1+n_{2-2}}}\right)\left(\frac{1}{n_{1}}+\frac{1}{n_{2}}\right)} \\
& \text { Where: } \\
& \mathrm{t}=\text { test of significance } \\
& X_{1}=\text { mean score of } \\
& \text { experimental class } \\
& X_{2}=\text { mean score of control } \\
& \text { class } \\
& S S_{1}=\text { the sum square of } \\
& \text { experimental class } \\
& S S_{2}=\text { the sum square of control } \\
& \text { class } \\
& n_{1}=\text { the total number of } \\
& \text { experimental class } \\
& n_{2}=\text { the total number of } \\
& \text { control class } \\
& \text { 2006) } \\
& \text { (Gay, Mills, Airasian, }
\end{aligned}
$$

\section{Results and Discussion}

In the pretest of experimental class, it was shown that ability of the first semester students of TKJJ Study Program in Civil Engineering Department of Politeknik Negeri Ambon in writing was still low. There were $24(92.30 \%)$ student was predicate in $\mathrm{D}$ - as very poor, one $(3.85 \%)$ students was predicate in $\mathrm{C}+$ as fair score, and just one $(3.85 \%)$ students was predicate B- as good.

But after giving the treatment as in the table above, it was shown that there was one $(3,85 \%)$ students were predicate AAs classification very good, two $(7.69 \%)$ students were predicate $\mathrm{B}+$ as classification good, four $(15.38 \%)$ students were B- as classification Good, eighteen $(69.23 \%)$ students were predicate B- as classification good, just one $(3.85 \%)$ students was predicate $\mathrm{C}^{+}$as classification fair. 
The pretest of control class showed that ability of the first semester students of TKJJ Study Program in Civil Engineering Department of Politeknik Negeri Ambon in writing is still low. there was one (4\%) students was predicate $\mathrm{C}+$ as classification fair, four (16\%) student who predicate $\mathrm{C}$ - as classification fair, three (12\%) students were predicate $\mathrm{D}+$ as classification very poor, and there were seventeen $(68, \%)$ students were Predicate D-. But after giving the conventional treatment, the table above shows no one students got predicate $\mathrm{A}$ and $\mathrm{B}$ as classification very good and good, there were two $(8 \%)$ students were predicate B as classification good, ten (40\%) students were predicate B- as classification good, eleventh $(44 \%)$ students were predicate $\mathrm{C}+$ as classification fair, one (4\%) students was predicate $\mathrm{C}$ and $\mathrm{C}$ - as classification fair.

\section{Experimental Class}

The following table describes the mean score of experimental class both of pretest and posttest.

Table 1. The mean score of the students of experimental class

\begin{tabular}{llll}
\hline \multicolumn{3}{c}{ experimental class } \\
& $\begin{array}{l}\text { Qualify } \\
\text { cation }\end{array}$ & Pretest & $\begin{array}{l}\text { Postte } \\
\text { st }\end{array}$ \\
\hline$(\overline{\mathrm{X})}>75(\mathrm{C})$ & Successful & - & 79.35 \\
$(\overline{\mathrm{X}})<75(\mathrm{C})$ & unsuccesfull & 47.77 & \\
\hline
\end{tabular}

The table above shows the mean score of experimental class both in pretest and in posttest. The mean score obtained by the students in experimental class for pre- test was 47,077 and it was categorized as unsuccessful qualification because is under of the standard achievement of curriculum 2013 was 75 . But the mean score for posttest was 79.35 , it was categorized as successful.

\section{Control Class}

The following table describes the mean score of experimental class both of pretest and of posttest.

Table 2. The mean score of the students of control class

\begin{tabular}{lllc}
\hline score & qualification & Pretest & Posttest \\
Score & & & \\
\hline$\overline{(X})>75(C)$ & unsuccessful & - & 73.96 \\
$\overline{(X)}<75(C)$ & unsuccessful & 49 & - \\
\hline
\end{tabular}

The table above shows that the mean score of control class both in pretest and posttest. The mean score obtained by the students was control class for pretest is 49 and it was categorized as unsuccessful qualification because it was under of the standard minimum achievement of Politeknik Negeri Ambon curriculum which took 75 as standard achievement.

\section{Hypothesis Testing}

The following table describes the t-test and the t-table value from the variables pretest and posttest of the class Experimental and control class.

Table 3. The t-Test of the students' pretest and posttest of the class Experimental and Control class.

The previous table shows that the t-test value and the t-table value. After applying t-test of testing hypothesis comparative two samples to Freedom $(\mathrm{df})=\mathrm{n} 1+\mathrm{n} 2-2$, the calculating of the degree of freedom was $(d f)=26+25-2=49$. The $t$-table value of the level of significant $(\alpha) 0.05$ and the degree of freedom (df) 49 is 1,684. Therefore, the t-test value (3.746) was higher than the t-table value $(1,684)$. It means that the null hypothesis (HO) rejected and the alternative hypothesis (HI) was accepted. It means that learning English by implementing Suggestopedia Learning Method develop students writing ability.

\section{Conclusion}

As facilitators, teachers have an important role in presenting learning material every day. Delivering material with fresh learning methods will foster new enthusiasm for students in following the learning process. Based on the previous chapter, the researcher concludes that the 
use of Suggestopedia Learning Method can improve the writing ability of the first semester students of TKJJ Study Program in Civil Engineering Department of Politeknik Negeri Ambon. It can be concluded that experimental class who had better writing ability than the students in control class who were taught through conventional method (scientific approach). It proved by the rejecting of null hypothesis (Ho) and accepting of alternative hypothesis (Hi), after the application of t-test formula of posttest where $\mathrm{t}$-test value is higher than t-table value.

\section{Acknowledgement}

Thanks to Renny James Betaubun, S.ST., M.T. as the head of Civil Engineering Department and all the students of first semester students of TKJJ Study Program in Civil Engineering Department of Politeknik Negeri Ambon for participating in this research.

\section{References}

Bancroft, W. J. (1999) Suggestopedia and Language Acquisition Variation on a Theme. Singapore: Gordon.

Dardjowijojo. S. (1996). "Lima Pendekatan Mutakhir dalam Pengajaran Bahasa" dalam Muljanto Sumardi (ed). Berbagai Pendekatan dalam Pengajaran Bahasa dan Sastra. Jakarta: Pelita Sinar Harapan.

Gay, Mills, Airasian. (2006). Educational Research; Competencies for Analysis and Applications: Eight Edition. Columbus Ohio. Person Merril Prentice Hall.

Harmer, J (2001), How to Teach Writing, (England: Pearson Education Limited, 2001)

Harmer, J (2007), How To Teach Writing, (England: Longman, 2007), p.33.
Hyland, K. (2002). Teaching and Researching Writing, Great Britain: Pearson Education.

Jakob, J. C. (2020). IMPLEMENTING COMMUNICATIVE FLUENCY ACTIVITIES AS LEARNING TECHNIQUE TO PROMOTE THE STUDENTSâ€TM ABILITY IN WRITING DESCRIPTIVE TEXT. Voice of English Learners, 1(2).

Lozanov, G. (1978). Suggestology and Outlines of Suggestopedy. New York: Gordon and Breach.

Lozanov, G. (1982). SUGGESTOLOGY AND SUGGESTOPEDIA. In R.E. Blair. Innovative approaches to language teaching Rowley, MA: New Bury House.

Meyers, A. (2005). Gateways to Academic Writing: Effective Sentences, Paragraphs, and Essays, (New York: Pearson Education, Inc, 2005), p. 2.

Pineda, C. (2013). Utilización de técnicas basadas en "Suggestopedia". Spain: Universidad de Valladolid.

Rahman. A. (2011). Teaching Writing to The Ninth Grade Students of SMPN 1 Pinrang by Paper Based Portfolio Learning And Electronic Portfolio (Comparative Study). Parepare. Thesis FKIP UMPAR.

Richards, J.C. and Rodgers, T.S. (2001). Approaches and Methods in Language Teaching (2nd ed.). Cambridge: Cambridge University Press. 